Balkan Araştırma Enstitüsü Dergisi / Journal of Balkan Research Institute Cilt/Volume 8, Say1/Number 2, Aralık/December 2019, ss. 235-260.

DOI: 10.30903/Balkan.657733

ARAŞTIRMA MAKALESI - RESEARCH ARTICLE

\title{
DEBRE FATİH SULTAN MEHMED (HÜNKÂR) CAMİİ
}

\author{
Tülay KARADAYI YENICE* - Barış GÖREN**
}

\begin{abstract}
ÖZ
Osmanlı döneminde Manastır vilayetine bağlı olan Debre şehri, 20. yüzyıl başlarına kadar Osmanlı hâkimiyetinde kalmıştır. Şehir Osmanlıların batıdaki fetihlerinde de önemli bir rol üstlenmiştir. Bu nedenle diğer tüm Balkan yerleşmelerinde olduğu gibi, Debre şehrinde de Osmanlı Devleti tarafindan imar faaliyetlerine önem verilmiş, camiler etrafinda geliştirilen çarşılar ile şehrin fiziki yapısına yön verilmiştir. Hünkâr Camisi olarak bilinen yapı, 1467 yılında Fatih Sultan Mehmed Han tarafından inşa ettirilmiştir. Cami şehir merkezinde yer almaktadır. Debre'de Osmanlı döneminde inşa edilen on üç camiden günümüze ulaşmış tek eserdir. Cami büyük bir hazire içerisinde bulunmaktadır. Hazirenin içerisinde bir de türbe yapısı bulunmaktadır. Günümüzde cami işlevini sürdüren yap1, Makedonya Anıtlar Kurulu tarafindan eski eser olarak tescil edilmiştir. Debre Fatih Sultan Mehmed Camisi üzerine günümüze dek mimari anlamda yapıyı konu alan monografik bir araştırmaya rastlanmamaktadır. Bu araştırmada Debre Fatih Sultan Mehmed Camisi'nin mimari karakteristikleri detaylı bir şekilde incelenmektedir. Araştırma sonucunda elde edilen bulguların, yapının restorasyon aşamasına katkı sağlayacağı düşünülmektedir.
\end{abstract}

Anahtar Kelimeler: Balkanlar, Debre, Hünkâr Camii, Makedonya, Osmanlı

\section{DEBAR FATIH SULTAN MEHMED (HUNKAR) MOSQUE}

\begin{abstract}
The city of Debar, a part of the province of Manastir during the Ottoman period, remained under the Ottoman rule until the beginning of the 20th century. The

* Dr. Öğretim Üyesi, Hasan Kalyoncu Üniversitesi, Güzel Sanatlar ve Mimarlık Fakültesi Mimarlık Bölümü, Gaziantep, ORCID: orcid.org/0000-0001-7063-6520, E-mektup: tulay.yenice@hku.edu.tr

** Mimar, Gören Mimarlık, Gaziantep, ORCID: orcid.org/0000-0002-7941-9685, E-mektup: hbarisgoren@gmail.com
\end{abstract}




\section{TÜLAY KARADAYI YENICE - BARIŞ GÖREN}

city has played an important role in the conquests of the Ottoman Empire in Eastern Europe and Balkans. For this reason, as in all other Balkan settlements, the Ottoman Empire prioritized the construction and development activities in the city of Debar and directed the bazaars around the mosques for the physical growth of the city. This building, also known as the Hunkar Mosque, was built in 1467 by Fatih Sultan Mehmed Khan. The mosque is located in the city centre of Debar. Hunkar Mosque is the only still standing monumental building from the thirteen mosques built in the Ottoman period. It is located in a great hazire that is burial area reserved for special people especially inside mosques or Sufi lodges. There is also a tomb building in the hazire. Nowadays, the building which is still functioning as a mosque is registered as a historical monument by the Macedonian Board of Monuments. There is no monographic research on the architectural structure of the building up to now. In this research, the architectural characteristics of the Fatih Sultan Mehmed Mosque are examined in detail. It is thought that the findings of the research will contribute to the restoration phase of the building.

Keywords: Balkans, Debar, Hunkar Mosque, Macedonia, Ottoman

\section{Giriş}

Balkanların önemli bir parçası olan Makedonya, 14. yüzyılın ikinci yarısından 20. yüzyılın ilk çeyreğine kadar Osmanlı egemenliğindeki coğrafyaların önemli ve doğal bir parçası olmuştur. Osmanlılar, Makedonya topraklarını ilk olarak 14. yüzyılın ikinci yarısından sonra Sultan I. Murad devrinde fethetmeye başlamışlardır. 1364 yılında Sırpsındığı veya Birinci Çirmen Muharebesi olarak bilinen savaşlarda Osmanlıların elde ettiği başarı, Türklerin Balkanlar'da hızla ilerlemelerini sağlamıştır. 1372 İkinci Çirmen veya Meriç Muharebesinde Osmanlı güçlerinin Batı Trakya ve Makedonya'daki Sırp Devleti'nin kuvvetlerine karşı elde edilen galibiyet, Makedonya'nın fetih yollarını açmıştır. ${ }^{1}$ Ancak Osmanlı Türklerinin Balkanlarda kalıcı olarak yerleşmeleri ancak Fatih Sultan Mehmed'in 1464 yılında ikinci bir fethi ile gerçekleştiğini söylemek mümkündür. ${ }^{2} \mathrm{Bu}$ fetihten itibaren bölge yurt edinilmeye, Anadolu'dan getirilen nüfusla iskân edilmeye başlanmıştır. Bölgenin sahip olduğu, sosyal, kültürel, ekonomik, siyasi ve askeri önem nedeniyle Osmanlılar Balkanlar bölgesine özel önem

\footnotetext{
${ }^{1}$ İsmail Hakkı Uzunçarşıllı, Osmanlı Tarihi, C. 1, Türk Tarih Kurumu Basımevi, Ankara 2011, s. $168-171$.

${ }^{2}$ Mehmet Zeki İbrahimgil, "Evliya Çelebi Seyahatnamesinde Ohri Sancağı", Sanat Tarihi Dergisi, Cilt: 22, Say1: 1, Nisan 2013, s. 11; Mehmet Z. İbrahimgil, "Balkanlar'daki Fatih Sultan Mehmed Camileri”, Balkanlarda İslam Medeniyeti II, Milletlerarası Sempozyumu Tebliğleri, Tiran Arnavutluk 4-7 Aralık 2003, s. 513-530.
} 


\section{DEBRE FATIHH SULTAN MEHMED (HÜNKÂR) CAMİSI}

göstermişlerdir. $\mathrm{Bu}$ önemi bölgede kalıcı yatırımlar ve imar faaliyetlerinden okumak mümkündür. Yaklaşık 550 yıllık süre içerisinde bölgedeki sosyal ve ekonomik hayatı canlandırmak üzere cami, çarşı, külliye, han, hamam, köprü gibi birçok mimari eser yapılmıştır.

Makedonya'nın Ohri bölgesinde bulunan Debre, Osmanlı egemenliğine Fatih Sultan Mehmed döneminde giren yerleşmelerden biridir. Şehir fetih camisine sahip Balkan yerleşmelerindendir. Debre'de Osmanlı döneminde inşa edilmiş cami yapılarından günümüze sadece Hünkâr Camisi olarak da bilinen Fatih Sultan Mehmed Camii ulaşmıştır. Cami şehir merkezinde yer almaktadır. Büyük bir hazire içerisinde bulunan cami yapısı ile birlikte bir de türbe yapısı bulunmaktadır. Cami çeşitli dönemlerde değişiklik ve onarımlara uğramıştır. Günümüzde cami işlevini sürdüren yapı, Makedonya Anıtlar Kurulu tarafından eski eser olarak tescil edilmiştir.

Debre Hünkâr Camisi üzerine günümüze dek mimari anlamda yapıyı konu edinen monografik bir araştırmaya rastlanmamaktadır. Bu araştırmada Balkanlarda, Osmanlı dönemi Fetih Camileri arasında yer alan ve döneminin özgün karakterini taşıyan Debre Fatih Sultan Mehmed Camii (Hünkâr Camisi), mimari karakteristiğiyle detaylı bir biçimde incelenmektedir. Diğer taraftan araştırmada hazire alanı, türbe ve cami yapısına ilişkin rölöve çalışmaları sayesinde yapıdaki bozulmalar, geçmiş dönem onarımları ve eklentileri analiz edilmektedir. Araştırma sonucunda elde edilen bulguların restorasyon-konservasyon çalışmalarına katkı sağlayacağı düşünülmektedir.

\section{Debre Tarihi}

Eski bir Osmanlı kenti olan Debre, Makedonca Debar, Arnavutça Diber veya Dibra olarak da bilinmektedir. Debre Makedonya'nın batısında, ülkenin idari sınıflanmasına göre ise güneybatı bölgesi sınırlarında yer alır. Oldukça dağlık bir coğrafyaya sahip olan şehrin etrafinda Dešat, Stogovo, Jablanica ve Bistra dağları bulunur. 2016 yılı nüfus verilerine göre Debre şehir nüfusu 20.784 kişidir. ${ }^{3}$

Tarihte Debre'den ilk defa M.Ö. 5. yüzyılda Herodot'un bahsettiği bilinmektedir. I. yüzyılda Strabo, Debre'yi bir İliryalı kabile diye kaydeder. 2. yüzyıl Roma kaynaklarında da adına rastlanan şehir, tarihsel süreç içerisinde Epir Despotluğu, Bulgarlar, Haçlılar, Bizanslılar ve Sirplar

\footnotetext{
${ }^{3}$ http://www.stat.gov.mk/PrikaziPoslednaPublikacija.aspx?id=11, (21.03.2019).
} 


\section{TÜLAY KARADAYI YENICE - BARIŞ GÖREN}

arasında el değiştirmiştir. ${ }^{4}$ 14. yüzyı1 Türk fetihlerinden 20. yüzyılda Balkan Savaşları'na kadar şehir, Osmanlı hâkimiyeti altında kalır. Debre 15. yüzyıldan itibaren Osmanlı fetihlerinin batıya doğru yayılmasında stratejik bir öneme sahip olmuştur. Şehrin, Yukarı Debre ve Aşağı Debre olarak ikiye ayrıldığı bilinmektedir. Bu bölgenin idari merkezi ise Yukarı Debre olmuştur. ${ }^{5}$ Şehrin çevresinin büyük ölçüde dağlık olmasının, ticari ve kültürel açıdan gelişimini olumsuz yönde etkilediğini düşündürmektedir. ${ }^{6}$

Kâtip Çelebi Cihannüma adlı eserinde Debri olarak adlandırdı̆̆ 1 Debre şehri için; Ohri, Kırçova ve Kalkandelen kazalarının arasında bir kaza ve kasaba olduğu, İstanbul'a 17 günlük uzaklıkta olduğunu belirtmektedir. Ayrıca Ohri Gölü'nün önemli bir ayağı olan Drim ismiyle bilinen büyük nehrin Debre nahiyesinden geçtiği belirtilmektedir:

"Feth-i dal ve sükûn-i bâ ve kesr-i râ ve sükûn-i yâ ile (Debri) Ohri ve Kırçova ve Kalkandelen kazâları meyanında vâki olmuş bir kasaba ve kazâ olub, Ístanbul'dan on yedi günde varllır. Ve Ohri gölünün ayağ Drim dimekle mă̆ruf nehr-i kebîr, Budiri nahiyesinden cereyan eder".?

Şehrin Osmanlı dönemindeki sosyokültürel durumuna ilişkin bilgiler oldukça kısıtlıdır. Nureski ${ }^{8}$, Debre şehrinin tezkirelere giren 1 divan şairiyle (Vecdi) en az şair yetiştiren şehirlerden biri olduğunu, ancak bir şairle bile olsa da dönemin edebiyatına ve şiirine katkı sağlamasının en azından ikinci derecede bir kültür merkezi olduğunu gösterdiğine işaret etmektedir. Avusturya konsolosu J. George von Hahn, 1864'te gördüğü Debre'nin 1863 'te 9.000 veya 10.000 nüfusu barındıran 2000 hanesinin bulunduğunu, bu nüfusun sadece 170'inin Hristiyan Bulgarlara ait olduğunu ve geri kalanının Müslüman Arnavutların evleri olduğunu belirtmektedir. George von Hahn aynı zamanda Debre'nin büyük bir çarşısı olduğunu ve silâh yapım

4 Machiel Kiel, "Debre", İslam Ansiklopedisi, https://islamansiklopedisi.org.tr/debre, (18.02.2019); Dmitry A. Shcheglov, Eratosthenes' Contribution to Ptolemy's Map of the World, The International Journal for the History of Cartography, 69:2, 2017, s. 159-175

${ }^{5}$ Djuneis Nureski, "Osmanlı Kaynaklarına Göre Kültür Merkezi Konumundaki Makedonya Şehirleri ve Özellikler”, Balkan Araştırma Enstitüsü Dergisi, Cilt/Volume 3, Say1/Number 1, Temmuz/July 2014, s. 63-102.

${ }^{6}$ Aleksander Stojanovski, Makedonija vo Turskoto Srednovekovie, Kultura, Skopje 1989, s. 194-200.

${ }^{7}$ Kâtip Çelebi, Cihannümâ - İklîm-i Rum, C. I, İstanbul, 1971, s. 88-89.

${ }^{8}$ Nureski, a.g.m. 


\section{DEBRE FATIHH SULTAN MEHMED (HÜNKÂR) CAMİSI}

ustalarından bahsetmektedir. ${ }^{9}$ Bununla birlikte $1466 / 1467$ yıllarında Debre'de Hıristiyanların 18 Tımar sahibi olduğu bilinmektedir. ${ }^{10}$ Debre'nin, 1787-1792 yılları arasında Osmanlı İmparatorluğu'nun Rusya ve Avusturya ile mücadele ettiği dönemde, diğer Balkan şehirleri gibi oluşan çeteler (krdzalis olarak da bilinmektedir) nedeniyle giderek istikrarsızlaştırılmıştır. ${ }^{11}$ $\mathrm{Bu}$ kargaşa ortamı 1900'lü yılların başlarına kadar sürmüştür. İç karışıklıklarda meydana gelen süreçler ve birçok savaş sırasında savaş alanlarında gelen dış yenilgiler, bölgede Osmanlıların giderek güç kaybetmesine yol açmıştır.

Atatürk'ün dedesi Kızıl Hafiz Ahmet Efendi'nin, Debre'nin bir köyünden olduğu bilinmektedir. Babası Ali Rıza Efendi, Debre Kocacık Köyü'nde dünyaya gelmiştir. ${ }^{12}$ Debre'nin merkezi, Osmanlı İmparatorluğu döneminde Debre-i Bâlâ adını taşımıştır (دبرهء بالا) Osmanlı Devleti’nin son yüzyılında Debre, Manastır Vilayeti'ne bağlı bir sancaktır. Debre bölgesindeki Osmanlı egemenliği 1912-1913 yılları itibarıyla sona ermiştir. Daha sonra Sırp, Hırvat ve Sloven Krallığı egemenliğinde kalmıştır. Krallık, sonrasında Yugoslavya Krallığı adıyla 1944 yılına bölgeye egemen olmuştur. Yugoslavya Krallığı ortadan kalkınca yerine Yugoslavya Sosyalist Federal Cumhuriyeti kurulmuştur. Bu dönemde de Debre, devam eden idari yapı içinde bulunmuştur. 1991 yılında Makedonya'nın Yugoslavya Sosyalist Federal Cumhuriyeti'nden bağımsızlığını ilan etmesiyle Debre, günümüz bağımsız Kuzey Makedonya Cumhuriyeti içinde yer almaktadır.

\section{Debre Fatih Sultan Mehmed (Hünkâr) Camisi}

Debre şehir merkezinde yer alan Fatih Sultan Mehmed Han Camisi (Hünkâr Camii), Makedonya Kültür Bakanlığı'nın RZZSK, 4.3.1968, 06213/1 Tescil Tarih ve Sayısı ile RZZSK, 4-808-13/15 RND Kayıt Numaralı Eski Eser olarak tescil edilmiştir. Fatih Sultan Mehmed Han Camisi, Debre'de Osmanlı döneminden kalma en önemli mimari eseridir (Şekil 1).

\footnotetext{
${ }^{9}$ J. George von Hahn, Reise durch die Gebiete des Drin und Wardar im auftrage der Kaiserl. Akademie der Wissenschaften, unternommen im Jahre 1863, Wien 1865, s. 360-364. (urn:nbn:de:bvb:355-ubr05324-0003-9).

${ }^{10}$ Aneta Shukarova, Mitko B. Panov,. Dragi Georgiev, Krste Bitovski, Ivan Katardziev Vanche Stojchev, Novica Veljanovski ve Todor Chepreganov, History of the Macedonian People, Ed. Todor Chepreganov, Institute of National History, Skopje 2008, s. 127.

${ }^{11}$ Shukarova vd., a.g.e.

12 Ali Güler, Atatürk'ün Soyu, Kızıloğuzlar ve Konyarlar, Berikan Yayınları, İstanbul 2014.
} 


\section{TÜLAY KARADAYI YENICE - BARIŞ GÖREN}

Cami giriș kapısı üzerinde, beș satır bozuk sülüs hatlı inşa kitabesi bulunmaktadır. İnşa kitabesinin alt satırında da tek satır olarak yazılmış tamir kitabesi yer almaktadır. İnşa kitabesinin tarihi, Hicrî 872 / Milâdî 1467'dir. Tamir kitabesinin tarihi ise, Hicrî 1357 / Milâdî 1941'dir. Ancak Hicrî 1357 tarihi, 1938-1939 yıllarına denk gelmektedir. Böylelikle tamir kitabesine tarih düşürmede hata yapıldığg ortaya çıkmaktadır.

İnşa kitabesinin transkripsiyonu şu şekildedir:

"Ya miftahu'l-ebvab iftah lenâ hayru'l-bâb

Sahibu'l-hayrat cennet-mekân ebu'l-feth ve'l-me gazi

Sultan Mehmed Han sene 872".

Tamir kitabesinin transkripsiyonu ise şu şekildedir:

“Tarih-i tamir sene 1357 M. 1941".

Tamir kitabesinin alt satırının sonradan ilave edildiği açıça izlenebilmektedir. Üst kısımda yer alan inşa kitabesinin harf karakterleri [h'lerin çengelleri gibi-] birbirini tutmamaktadır. Tamir kitabesinin inşa kitabesinde bir bütünlük oluşturması amacıyla alt kısmına yazıldığı tahmin edilmektedir.

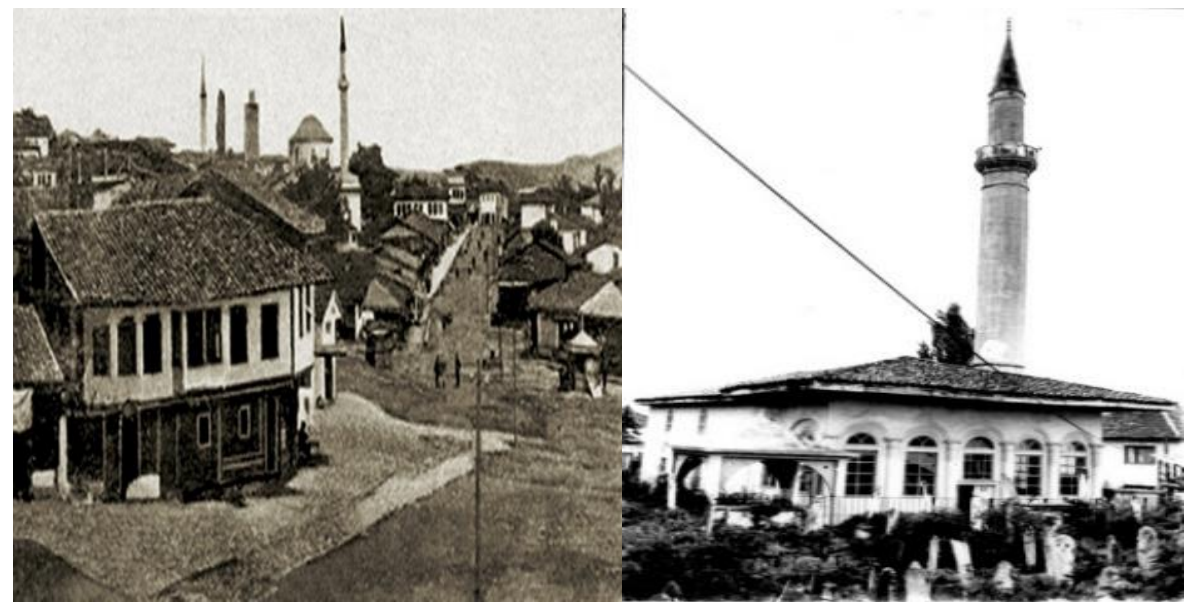

Şekil 1. 20. yüzyıl başlarında Debre ve Hünkâr Camisi (Makedonya Kültür Bakanlı̆̆ Arşivi) 


\section{DEBRE FATİH SULTAN MEHMED (HÜNKÂR) CAMİSI}

\subsection{Caminin geçirmiş olduğu onarımlar}

Osmanlı döneminde yapıya ait çeşitli kayıtlarda zaman zaman onarım ve bakım gördüğü bilinmektedir. Caminin Osmanlı döneminde geçirdiği tamiratlarla ilgili arşiv belgeleri ve transkripsiyonları şu şekildedir:

Hicrî 11 Şevval 1304: Fatih Sultan Mehmed'in Debre-i Bâlâ'da ihya ettiği caminin minaresinin tamiri. ${ }^{13}$

\section{Evkâf-ı Hümâyun Nezâret-i Celîlesine}

\section{1 Şevvâl 1304 Fi 21 Haziran 1303}

Cennet-mekân Fatih Sultan Mehmed Han tâbe serâh hazretlerinin Debre-i Bâlâ nam-ı diğer Rahovnik kasabasında ihyâ-kerdesi olan câmi-i şerifin ta 'mîrine lüzum görülen minaresi masârif-i ta 'mîriyyesinin müşârünileyh hazretlerinin Dersaâdet'teki evkâf-ı şerifesi vâridâtından olarak nezâret-i celîlerinden i 'tâsı veya diğer sûretle tesviyesi hakkında bazı ifâdâtı hâvî Manastır Vilâyeti İdare Meclisi'nden meb'us mazbata melfûfuyla beraber irsâl kulınmış olmağla meâline nazaran iktizâsının îfâ ve ifâdesi husûsuna himem-i aliyye-i dâverîleri derkâr buyrulmak bâbında.

Hicri 16 Rebiülevvel 1305: Debre-i Bâlâ kazasında Fatih Sultan Mehmed Han adına yapılmış olan caminin minaresinin tamir masraflarının ödenmesi. ${ }^{14}$

\section{Evkâf-ı Hümâyun Nezâreti Celîlesine}

16 Rebî̀ül-evvel sene 1305 Fi 19 Teşrîn-i Sânî 1303

Cennet-mekân Fatih Sultan Mehmed Han tâbe serâh hazretlerinin Debre-i Bâlâ nam-ı diğer Rahovnik kasabasında ihyâ-kerdesi olan câmi-i şerif minaresinin masârif-i ta 'mîriyyesi bulunan 8755 kuruşun müşârün-ileyh hazretlerinin Dersaâdet'teki evkâf-l vâridâtından olarak nezâret-i celîlerinden i'tâsı veya sûret-i âhiri ile tesviyesi muktezâsı hakkında Manastır Vilâyeti İdare Meclisi'nden meb 'us mazbata melfûfuyla beraber 20 Haziran 303 tarihinde bi't-tezkere nezâret-i celîlerine gönderilmiștir. Te 'kîdi ve bazı

${ }^{13}$ BOA, DH.MKT, 1428/113.

${ }^{14}$ BOA, DH.MKT, 1467/30. 


\section{TÜLAY KARADAYI YENICE - BARIŞ GÖREN}

ifadeyi hâvî bu kere dahi vilâyet-i müşârün-ileyhden alınan tahrîrât leffen sû$i$ âlî-i nezâret penâhîlerine irsâl kılınmış olmağla birleştirilerek iktizâ'sının îfâ ve ifâdesine himem-i aliyye-i dâverîleri der-kâr buyrulmak bâbında.

Hicri 15 Cemaziyelahir 1306: Debre-i Bâlâ'da Fatih Sultan Mehmed Han'ın evkafı dâhilinde bulunan camiye ait tamir masrafının Evkaf1 Hümayun Nezareti’nce karşılanması gerektiği. ${ }^{15}$

\section{Zi'l-ka'de 1305 Fi 19 Temmuz 1304}

İsbu ve diğer iki kut'a tezkere-i aliyye-i nezâret penâhîleri melfûfatı ile beraber meclis-i idare-i evkâfa lede'l-havâle câmi-i şerife mezkûr hakan müşârün-ileyh hazretlere vakfi dâhilinde olmadiğı ve olsa bile vakf müşârünileyh müstagrık-ı düyûn bulunduğu gibi melfûfat-l mezkûre miyânında bulunan keşf defterinde fenn-i mi 'mâriyye muvâfik olmadiğ şehr-emâneti celîlesi hendese-hânesinden beyân olunmuş olduğundan ba'de îcâbı icrâ' olunmak üzere evvel emrde fenn ve kaideye tatbîkan matluba muvâfik diğer bir kut'a keşf defteri tanzîm ve irsâl olunması masârif-i ta 'mîriyyede oraca münâsib bir karşıllı bulunarak cânib-i hazineye iş 'âr-ı keyfiyyet kılınması lazım geleceğinden keyfiyyetin ol vechle mahalline iş' $\hat{a} r$ buyrulması husûsunun cevaben izbârı meclis-i mezbûr kararıla masârifât idaresinden ifade olunmağla ol babda. Fi 22 Zi'l-ka'de 1305 ve fi 19 Temmuz 1304.

\section{Cemaziyelahir 1306 Fi 4 Şubat 1304}

İşbu cevab-ı âli-i âsaf-âneleri meâli ma lûm-ı âcizi olarak ol babda bi't-tekrar sebk eden isti 'lâma cevaben Manastır Vilâyet-i Celîlesinden meb 'us tahrîrât melfûfatıyla ve evrâk-ı müteferri' $-i$ mezkûrenin iâdesiyle sû-i âli-i dâverîlerine irsâl kllındı. Mütâlaasına müstebân olacă̆ı üzere câmi-i şerif mezkûr cennet-mekân Fatih Sultan Mehmed Han Hazretlerinin evkâfi dâhilinde olmadiğı ve masârif-i mezkûreye mahallince karşıllı tedâriki imkân tahtında olmadığı gösterilmiş olmağla sûret-i hâlî nazaran iktizâsından îfâsı tevakkuf himem-i aliyye ol bâbda nezâret penâhîleridir.

\footnotetext{
${ }^{15}$ BOA, DH.MKT, 1594/94.
} 


\section{DEBRE FATİH SULTAN MEHMED (HÜNKÂR) CAMİSI}

\subsection{Mimari Özellikleri}

Fatih Sultan Mehmed (Hünkâr) Camisi, Makedonya'da Fatih Sultan Mehmed'in adını taşıyan ve Debre şehrinde de Osmanlı İmparatorluğu tarafindan inşa edildiği bilinen on üç camiden ayakta kalan tek camidir. Caminin plan tipolojisi incelendiğinde, erken dönem cami plan tipolojilerine benzerliği söz konusudur. Yapının tek bir harim ve önünde son cemaat bölümünden oluşan bir plan şeması vardır. Cami oldukça geniş bir hazirenin içerisinde yer almaktadır.

Yap1 15. yüzyılda Balkan topraklarında inşa edilen kırma çatılı camiler grubunda incelenebilir. Bu camiler balkan topraklarında değişik bölgelerde inșa edilmişlerdir. Bulgaristan'ın Dobriç Şehrinin Balçık bölgesindeki Turgut Reis Camii, Varna Şehrindeki Hayriye Camii, Makedonya'nın Ohri şehrindeki Hacı Turgud Camii, Hacı Hamza Camii, Karabey camii, Göl camii bu camilere örnekler olarak sayılabilirler. ${ }^{16}$ (Şekil 2). Camilerin yapıldığı bölgeler farklı olsa da çatı örtüsü bakımından farklılık bulunmamaktadır. Plan şeması olarak Osmanlı ilk dönem camilerinin özelliklerini taşırlar.
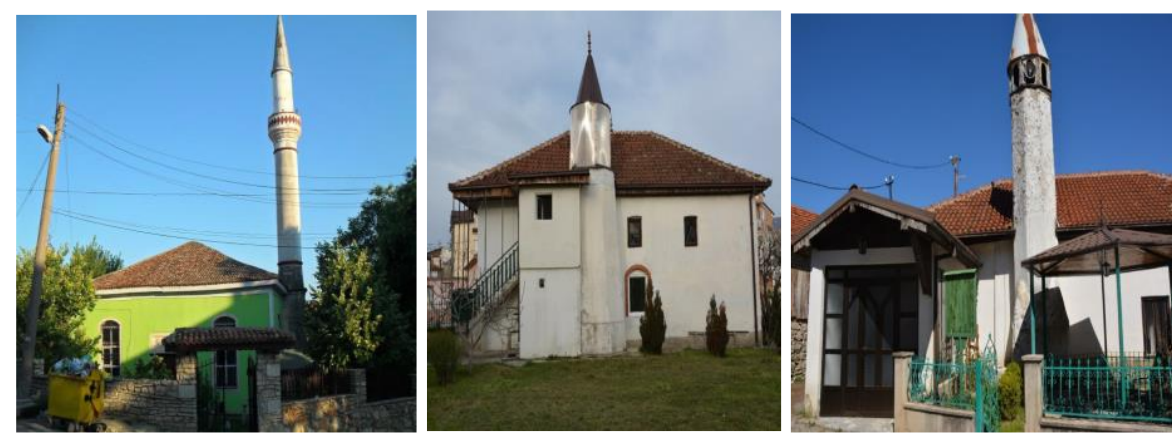

Şekil 2. Balçık Turgud Reis Camii (solda) (Bahriye Güray Gülyüz, 2019), Ohri Göl Camii (ortada), Ohri Karabey Camii (sağda) (Yılmaz ve Elmas, 2018).

\footnotetext{
${ }^{16}$ Bahriye Güray Gülyüz, "Osmanlı Geleneğinde Sakal-1 Şerifin Yeri ve Bulgaristan’da Sakal1 Şerif Muhafazalı Camiler”, Balkan Araştırma Enstitüsü Dergisi / Journal of Balkan Research Institute Cilt 8, Say1 1, 2019, s. 85-111. Edip Y1lmaz, Erdal Elmas, “Ohri'deki (Makedonya) Osmanlı Dönemi Camileri”, Anasay, Sayı 4, 2018, s. 47-82.
} 
TÜLAY KARADAYI YENICE - BARIŞ GÖREN

\subsubsection{Harim Bölümü}

Harim kısmı, dış ölçülere göre 12.70x9.38 m. boyutlarında, dikdörtgen planlıdır. Duvarlar $90 \mathrm{~cm}$ kalınlığında taştan yapılmıştır. İç mekân büyüklügü $61 \mathrm{~m}^{2}$ dir. Harim kısmının kuzeybatı ucunda iki katlı ahşap kadınlar mahfili bulunmaktadır. Kadınlar mahfilinden çıkışı sağlanan minare, harimin batı köşesine yerleştirilmiştir (Şekil 3).

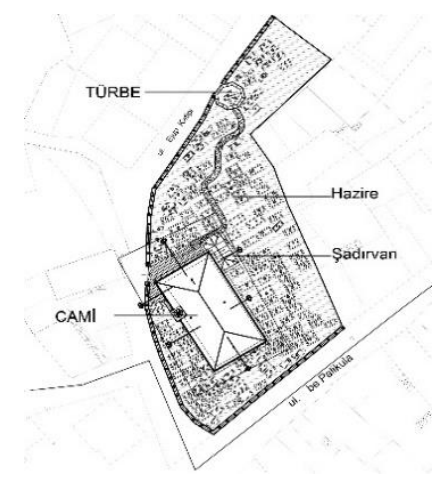

Hünkâr Camisi vaziyet planı

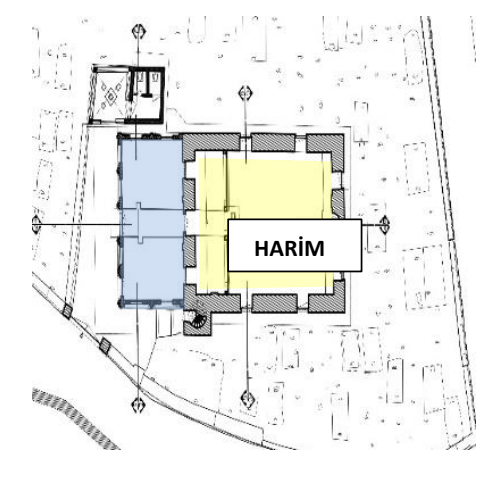

Hünkâr Camisi plan şeması

Şekil 3. Hünkâr Camisi vaziyet planı ve plan şeması

Harim kısmın güneydoğu (kıble yönü) yönünde duvarın tam ortasında mukarnaslı mihrap nişi bulunmaktadır. Mihrap nişi $173 \mathrm{~cm}$ genişliğinde, $58 \mathrm{~cm}$ derinliğinde yapılmıştır. Mihrabın yüksekliği $337 \mathrm{~cm}$ 'dir ve bunun $250 \mathrm{~cm}$ denk gelen yükseklikten tepe noktasına kadar taşıyıcı özelliğinin yanında zengin bir görselliğe sahip olan mukarnaslı bölüm yer almaktadır. Mukarnaslı bölümün her iki yanında sekiz yivli, çiçek görünümlü kabaralar bulunmaktadır. Mukarnasların ve kabaraların üzerinde ise mihrap kitabesi görünmektedir. Bu kitabede; “...Zekeriyya Meryem'in bulunduğu mihraba her girdiğinde..." anlamına gelen; "Kale sübhanehu ve Teala Küllema dehale aleyha Zekeriyya el-mihrab" yazılıdır.

Mihrabın zemini mermer taklidi bir süslemeyle yapılmış yağlı boyalıdır. Mihrabın önünde, mihrap duvarı boyunca $72 \mathrm{~cm}$ genişliğinde, 28 $\mathrm{cm}$ yüksekliğinde ahşap bir seki bulunmaktadır. Mihrabın güneybatısında ahşap bir minber bulunmaktadır. Bu minber klasik dönem Osmanlı minber 


\section{DEBRE FATIHH SULTAN MEHMED (HÜNKÂR) CAMİSI}

elemanlarının (Kapı, merdiven, korkuluk, aynalık, dolap, şerefe, külah ve alem) tamamına sahiptir. Minberin kapısında 11 basamakla vaaz verilen, şerefe kısmına ulaşılmaktadır. Minberin aynalık bölümündeki süslemelerinde 20. yüzyıla ait bezeme motifleri dikkat çekmektedir. Bu da minberin yapıya ilk yapıldığı dönem değil, yapıya ait kayıtlardaki son onarım sırasında eklenmiş olabileceğini düşündürmektedir. Minberin yerden alemin en üst noktasına kadar olan uzunluğu $490 \mathrm{~cm}$ 'dir. Yine caminin bu bölümündeki duvarda mihrap nişinin iki yanında, simetrik pencereler yer almaktadır. Alt kottaki pencereler dikdörtgen formludur. Üst kat pencerelerin ise üzeri basit kemerlidir (Şekil 4). Kuzeydoğu ve güneybatı duvarlarındaki sekiz adet pencere harim kısmını aydınlatmaktadır. Bu pencereler her iki duvarda da alt kotta iki adet ve dikdörtgen formludur. $\mathrm{Bu}$ pencerelerin üzerlerinde ise kemerli tepe pencereleri yer almaktadır.
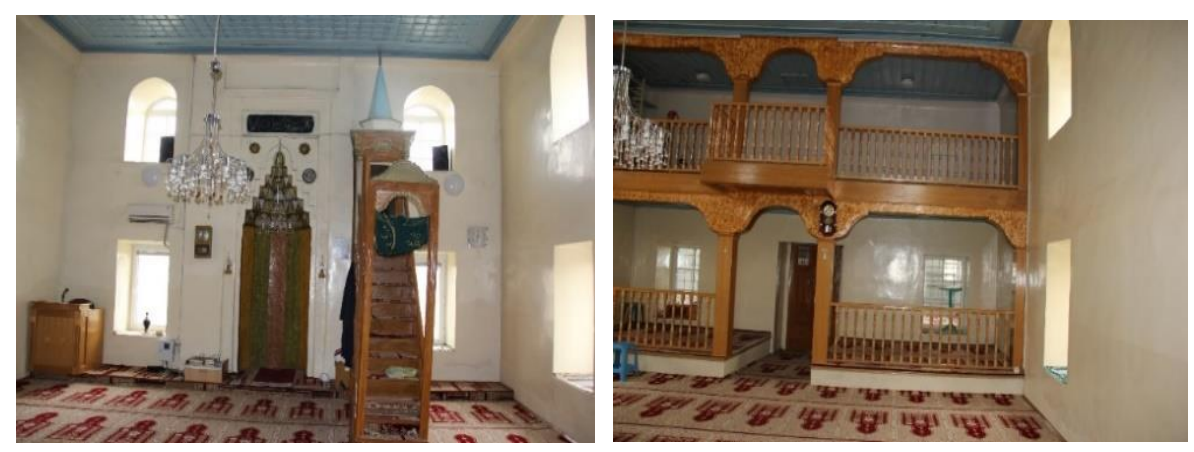

Şekil 4. Cami mihrap (soldaki resim) ve mahfil (sağdaki resim) bölümleri

Harim giriş kapısı tam mihrap aksında bulunmaktadır. Kapının bulunduğu bölümün her iki tarafında da ahşap kadınlar mahfili bulunmaktadır. $14 \mathrm{~cm}$ yüksekliğinde bir basamakla çıkılan halı kaplı alan kadınların ibadeti için ayrılan bölümdür. Kadınlar mahfili iki katlıdır. Üst kata mekânın batı köşesindeki ahşap merdiven ile çıkılmaktadır. Üst kat ahşaptan yapılmıştır. Harim kapısının üzerine gelen bölümde bu balkon daha da geniş tutularak balkon ifadesi güçlendirilmiştir. Harim bölümünde tavan kaplaması kare şeklinde çıtakâri tavan ile kaplanmış iken kadınlar mahfilinde çıtakâri tavan yatay çizgiler şeklinde kapatılmıştır. Bir başka ifadeyle mekân kullanımları içerisindeki farklılıklar, tavanda kullanılan çıta desenleri ile de hissettirilmektedir. 
Yapının kuzey batı duvarında ve giriş kapısının yan taraflarında simetrik dikdörtgen pencereler vardır. Aynı cephenin üst kotunda iki adet dikdörtgen pencere daha bulunmaktadır. Bu pencereler kadınlar mahfiline açılmaktadır. Caminin bütün alt kat pencereleri lokma demir parmaklıklıdır. Harimin bölümünün zemini ise ahşap kaplamadır. Ahşap kaplamanın üzeri halı ile örtülüdür. Bu bölümünün üzeri ahşap çitalı tavan ile örtülü ve mavi boyalıdır. Merkezi noktaya isabet eden kısımda yarıçap $50 \mathrm{~cm}$ olan sekizgen tavan süslemesi bulunmaktadır. Bu tavan süslemesindeki motiflerde, minberdeki motifler ile benzeşmektedir. Motif ve renkler 20. yüzyıl süslemeleridir. $\mathrm{Bu}$ nedenle bu süslemeli tavan göbeğinin de son onarım eki olduğu düşünülmektedir.

Günümüzde caminin pencereleri pvc esaslı, duvarları ise beyaz yağlı boya ile boyalıdır. Sadece kuzeydoğu duvarında kalem işi bir levha açıkta görülebilmektedir. Yazıda dört halifelerden "Osman" adı yazılıdır (Şekil 5). Duvar yüzeylerindeki beyaz yağlı boyanın dikkatlice temizlemesi neticesinde diğer duvarlardan da, diğer halifelerin adları ile Allah ve Muhammed (SAV) yazılı hatların çıkacağı tahmin edilmektedir.
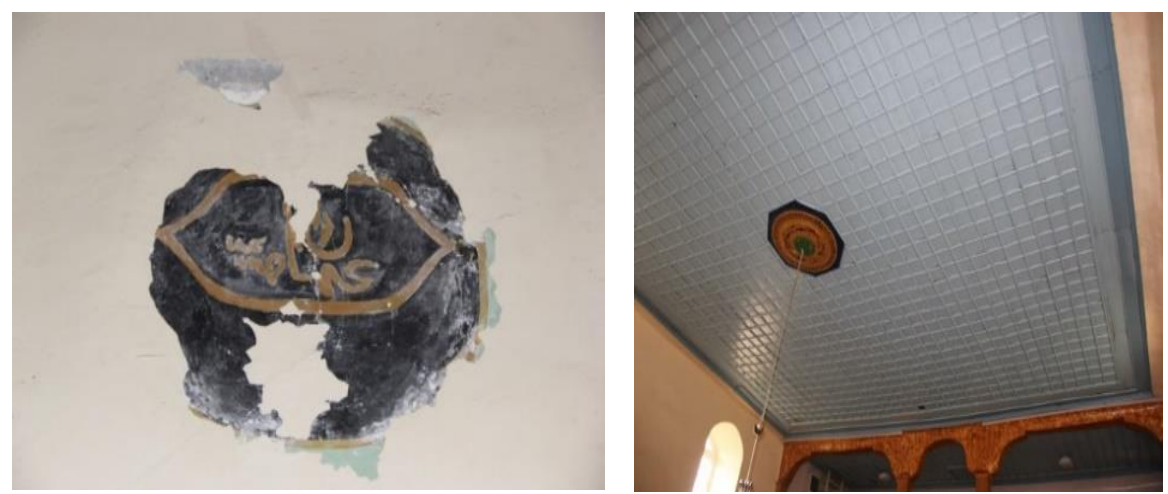

Şekil 5. Harim bölümü kalem işi örneği ve ahşap tavanı

\subsubsection{Son Cemaat Bölümü}

Debre Fatih Sultan Mehmed Camisi'nin son cemaat bölümünün Osmanlı hâkimiyetinden sonraki bir tarihte deprem, yangın, tahribat, kundaklama ve benzeri nedenlerden dolayı çatılı yapıldığ tahmin edilmektedir. Nitekim Ekrem Hakkı Ayverdi'nin de yapıda yaptığı tespit ve incelemelerde son cemaat bölümünün orijinalinde üç kubbeli olduğu 


\section{DEBRE FATİH SULTAN MEHMED (HÜNKÂR) CAMİSI}

kanaatini taşıdığı bilinmektedir. ${ }^{17}$ Caminin plan tipolojisinin ilk dönem örnekleri ile aynı olduğu düşünüldüğünde de son cemaat bölümünün üç kubbeli olması ve ortadaki kubbenin daha yüksek olması gerektiği düşünülebilir. Ancak günümüzde yapının kubbeli olduğuna dair iz veya buluntuya rastlanmamaktadır. Bu nedenle yapının kubbeli olduğunu kesin olarak iddia etmek için yeterli kanıt olmadığı söylenebilir (Şekil 6 ve 7).
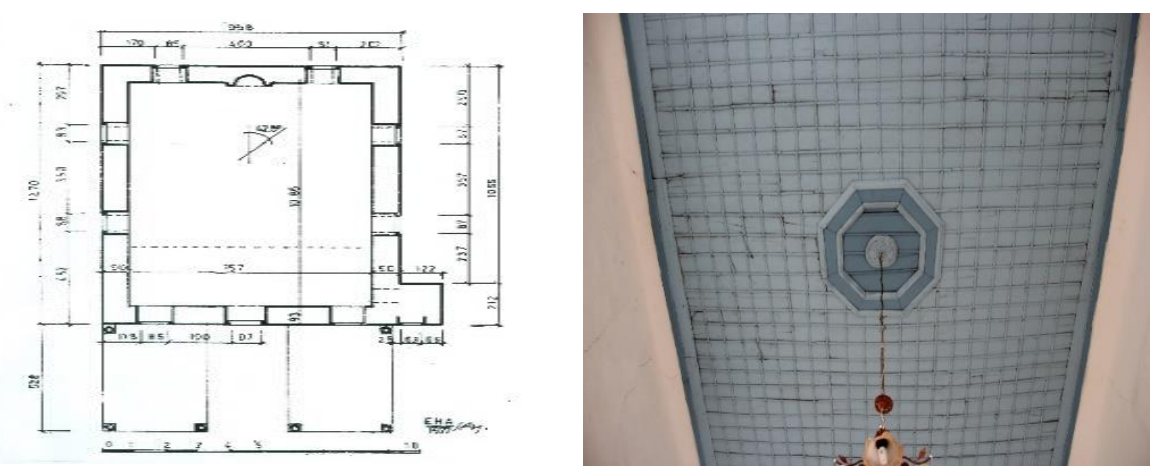

Şekil 6. Ekrem Hakkı Ayverdi plan çizimi (solda) (Ayverdi, 2000) ve günümüz son cemaat bölümü tavanı
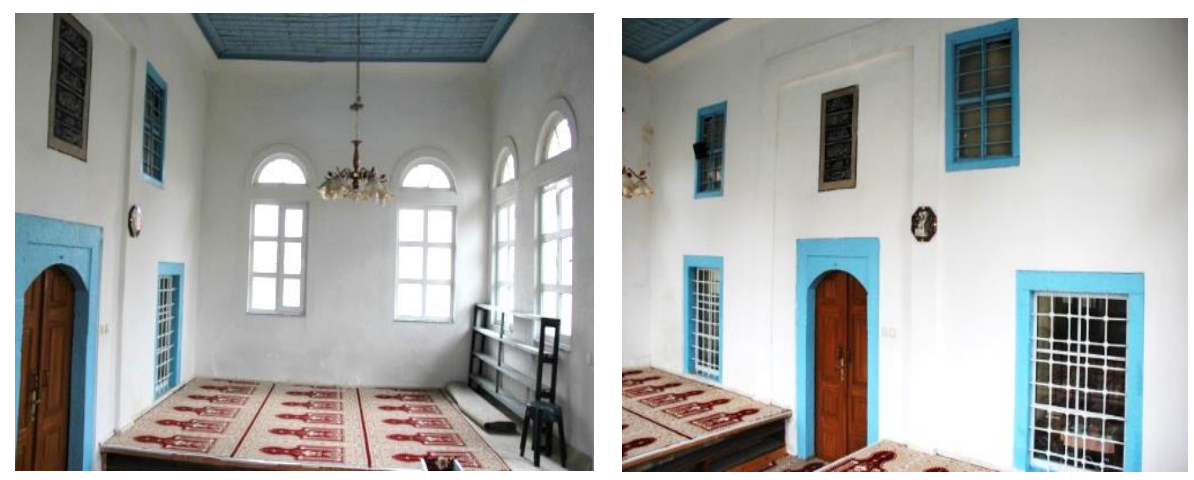

Şekil 7. Debre Hünkâr Camisi son cemaat bölümünün mevcut durumu

Son cemaat bölümünün harim kısmının kuzeybatısında yer almaktadır. 480 x $847 \mathrm{~cm}$ boyutlarındaki dikdörtgen mekân yaklaşık 40 $\mathrm{m}^{2}$ 'dir. Harim kapısının tam karşısında kuzeybatıdaki pvc bir kapıyla mekâna

${ }^{17}$ Ekrem Hakkı, Ayverdi, Avrupa'da Osmanlı Mimari Eserleri, Yugoslavya, C. 2, İstanbul 2000, s. 139. 
giriş sağlanmaktadır. Mekânda giriş kapılarının bulunduğu bölümün yanlarında $58 \mathrm{~cm}$ yüksekliğinde ahşap platformla kot farkı oluşturulmuştur. Mekânın döşemesi mermerdir. Platformun olduğu kısımlarda mermer döşeme ahşabın altında kalmıştır. Ahşap platformun olduğu bölüm ise halı kaplıdır. Mekânın güneydoğu duvarında harime girişi sağlayan kemerli ahşap bir kapı, kapının yanlarında geçme demir parmaklıklı iki adet ahşap pencere bulunmaktadır. Kapının üzerinde kitabe, kitabenin yanlarında ise lokma demir parmaklıklı iki adet pvc pencere bulunmaktadır. Kap1 ve pencere kenarları mavi renk boya ile şerit şeklinde boyanmıştır. Mekânın kuzeydoğu ve güneybatı duvarlarında ikişer adet kemerli pvc pencere bulunmaktadır. Mekânın kuzeybatı cephesinde de beş adet kemerli pvc pencere bulunmaktadır. Cephe duvarlarında yer yer kılcal çatlaklar mevcuttur.

Cami yapısı üzerinde yerinde yapılan incelemelerde, son cemaat bölümünün kapatıldığı, duvarlar arasına on sütun ile sekiz pencere yerleştirildiği ve camiyle aynı çatı altına alındığı tespit edilmiştir. Harimin dikdörtgen tavanı ile son cemaat bölümünün tavanı benzer biçimde ahşap kare motif çıtakâridir. Her iki tavanın da 1938-1939 yıllarındaki onarımda yenilendiği yapıdaki izlerden tahmin edilmektedir. Yapının çatısı günümüzde ahşap kırma çatı üzeri Marsilya kiremit döşemelidir. Eski bir fotoğrafında çatının Alaturka (oluklu) kiremitle örtülü olduğu görülmektedir. Son cemaat bölümünde kullanılan malzeme farklılığ ile burada yer alan sütunlar ve sütun başlıklarından bu kısmında, minarenin tamiratı esnasında yapıldığı tespit edilmektedir.

\subsubsection{Minare}

Minare yapının batı cephesinde, son cemaat bölümü ile harimin kesiştiği köşede yer almaktadır. Minareye hazireye açılan kaidesindeki demir bir kapı ile girilmektedir. Kaidesi kesme taş, gövdesi mozaik sıvalıdır. Minare 29,35 m yüksekliğindedir. Tek şerefesi bulunmaktadır. Şerefe kısmında mermer malzeme kullanılmıştır. 4,67 metre olan külah bölümü sac kaplamadır (Şekil 8). Başbakanlık Osmanlı Arşivi'nde yapılan incelemeler sonucunda ortaya çıkan arşiv belgelerinde görüldügü üzere Hicrî 11 Şevval 1304 (3 Temmuz 1887)'de caminin kesme taştan inşa edilen minaresinin tamir edildiği tespit edilmektedir. 


\section{DEBRE FATİH SULTAN MEHMED (HÜNKÂR) CAMİSI}
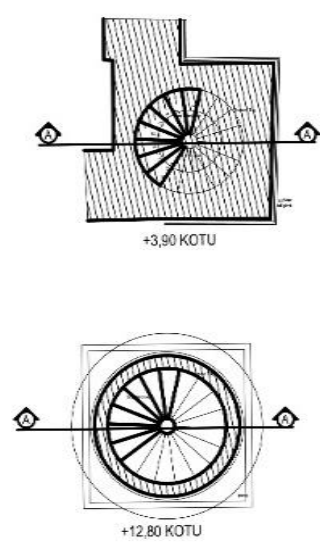

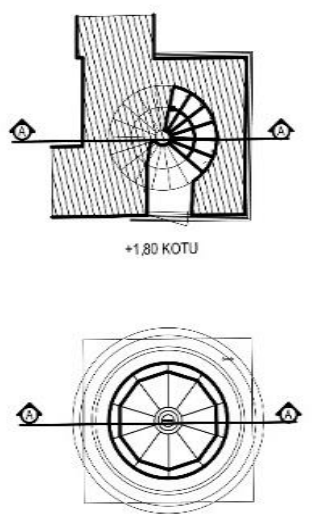

CATI PLANI
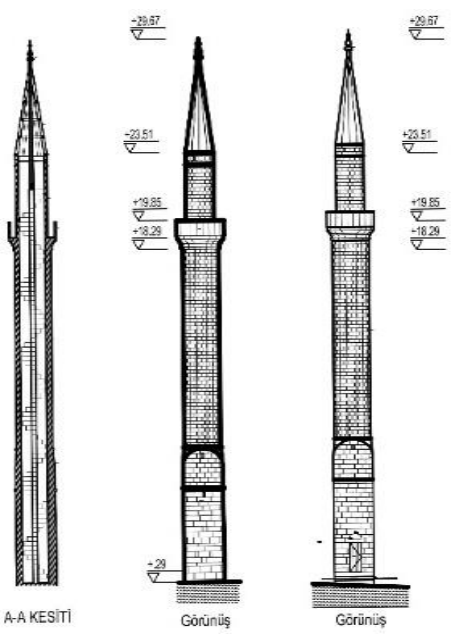

Şekil 8. Minare Plan-Kesit ve görünüşleri

Rölöve çalışmaları esnasında minarenin temel sisteminin incelenmesi amacıyla yapıya bitişik olarak $2 \mathrm{~m}$ derinliğinde muayene çukuru açılmış ve elde edilen bulgular minare temelinin kesme taştan yapıldığını ve en az $2 \mathrm{~m}$ derinliğine kadar indiğini göstermiştir. Temel taşlarında eksenel yükten kaynaklı herhangi bir bozulmaya rastlanmamıştır.

\subsection{4. Şadırvan ve Islak Hacimler}

Şadırvan ve tuvalet olarak kullanılan ıslak hacimler yapının doğu köşesinde yer almaktadır. Caminin 1900'lü yılların başına tarihlenen arşiv fotoğrafında, doğu köşede şadırvanı yer almaktadır. Günümüzdeki mevcut şadırvan ile tuvaletler ise, 28 Nisan 1986 'da inşa edilmiştir. Şadırvan yapısına üç tarafından kemerli açıklıklardan girilmektedir (Şekil 9).

Şadırvan bölümünün yerleri $30 \times 30 \mathrm{~cm}$ ölçülerinde fayans kaplamadır. Duvarları ise briket ve mozaiktir. Tavan ise betonarmedir. Betonarme çatının üzeri hafif bir eğimle külah şekline getirilerek şadırvan bölümünün üzeri kapatılmıştır. Şadırvan yapısında herhangi bir özgünlük söz konusu değildir. Betonarme şadırvanın, caminin restitüsyonu esnasında çıkarılacak malzemeyle eski fotoğrafından da faydalanılarak mimari üslubuna uygun biçimde yeniden inşa edilmesi düşünülmelidir. 


\section{TÜLAY KARADAYI YENICE - BARIŞ GÖREN}
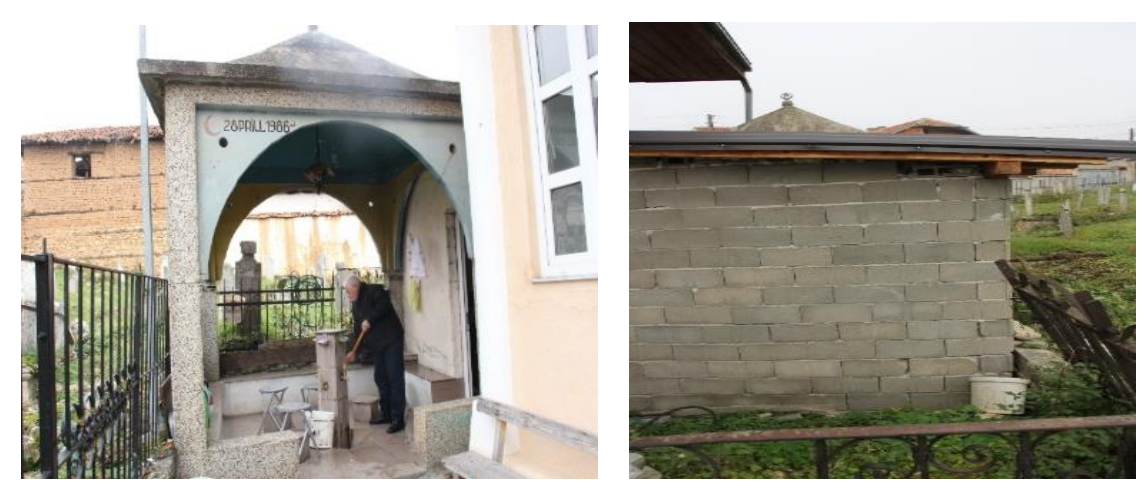

Şekil 9. Debre Hünkâr Cami’nin şadırvan ve 1slak hacim bölümleri

Şadırvanın güneydoğu duvarına bitişik bir pvc kapıdan tuvaletlere girilmektedir. Bu bölümde iki adet lavabo ve iki adet, alaturka tuvalet kabini yer almaktadır. Zemin döşemesi ve duvarları fayans kaplıdır. Betonarme tavan ise badanalıdır. Yapı dış cephede ise badanasız ve boyasız olarak, briket duvar hali ile görülmektedir. Bu durumda da tarihi yapı ile tezat oluşturmakta ve baraka görüntüsü yaratmaktadır. Tuvalet olarak kullanılan bu yapı tarihi esere oldukça yakın ve kötü bir mimariye sahip olduğu için yıkılması ve uygun bir yere tekrar inşa edilmeleri zorunlu görülmektedir.

\subsubsection{Hazire ve Sadık Paşa Türbesi}

Debre Fatih Sultan Mehmed (Hünkâr) Camisi geniş ve oldukça eski bir hazireye sahiptir (Şekil 10). Hazire bölümüne doğu cephesindeki demir kap1 ile giriş sağlanmaktadır. Giriş bölümünün döşemesi bazalttır. Hazire bölümünün etrafi kesme taş duvar ile örülmüştür. Ve demir korkuluk ile çevrelenmiştir. Bu bölümde toplam 123 adet mezar tespit edilmiştir (Şekil 11). Hazirenin kuzeybatısında Sadık Paşa Türbesi yer almakta ve içerisinde iki adet mezar bulunmaktadır. Türbenin adı; yapının içerisindeki en eski tarihli Sadık Paşa kabrine göre verilmiştir. Yapının, Sadık Paşa'nın mezar taşındaki tarihe göre; Hicrî 1210 (Milâdî 1795-96)'da inşa edildiği tahmin edilmektedir.

Bu türbenin en önemli özelliği Baldaken tarzında olmasıdır. Bilindiği üzere Türklerin mezarları anıtlaştırma geleneği İslam öncesi inanışlarından 


\section{DEBRE FATİH SULTAN MEHMED (HÜNKÂR) CAMİSI}

bu yana devam etmiştir. ${ }^{18}$ İslam'ın kabulü ile bu gelenek din, devlet adamlarının ve halkın önemli verdiği şahısların mezarlarının anıtsal nitelikte yapımı ile devam ettirmişlerdir. Bu ayı zamanda İslam mimarisinde türbe denilen yapı tipini ortaya çıkarmışladır. İran ateşgedelerinden kaynaklandığı ve Roma devri sunaklarından da etkilendiği görülen Baldaken tarzı, Türklerde türbe mimarisinde kendini ilk Müslüman-Türk devletlerinde göstermeye başlamıştır. Türklerin Anadolu'ya gelişinden sonra ilk örneklerini Beylikler devrinde görmeye başladığımız Baldaken tarzı türbelerin en seçkin örneklerine Balkanlarda rastlamak mümkündür ${ }^{19}$.
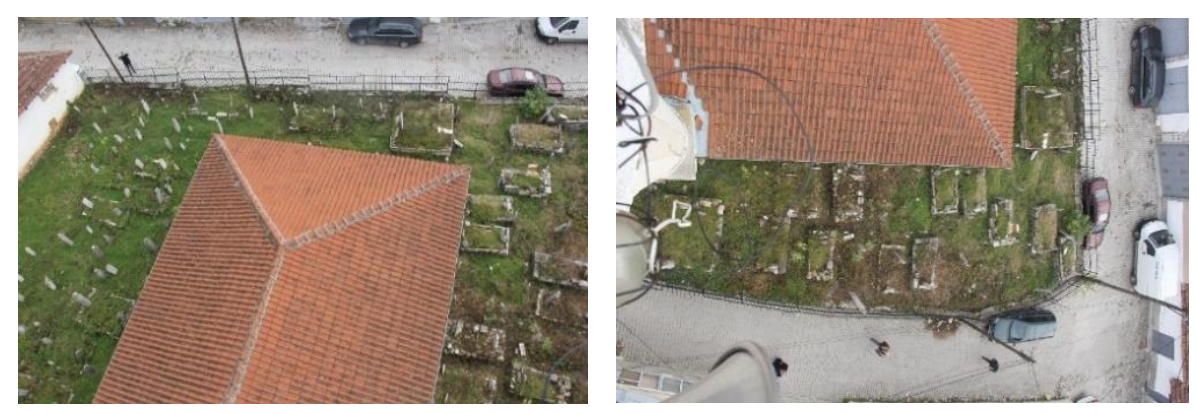

Şekil 10. Hazire görünümü
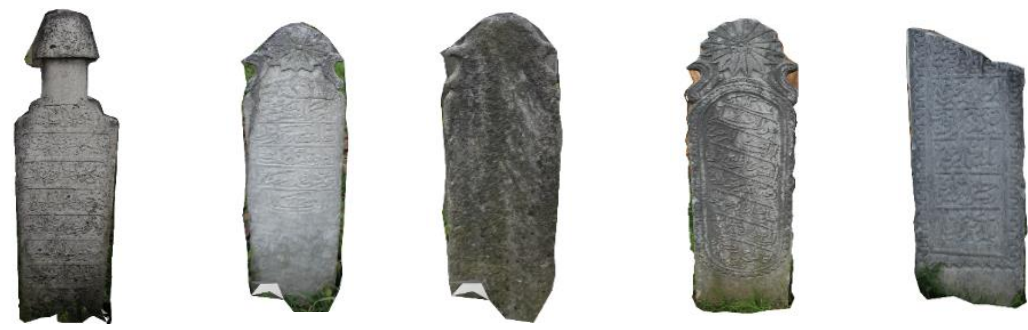

Şekil 11. Hazire içerisinde mevcut mezar taşı örnekleri

\footnotetext{
18 Osman Nuri Dülgerler, Tülay Karadayı, “Türklerde Anıt Mimarisinin Bir Örneği; Konya Atatürk Anıtı”, Selçuk Üniversitesi Mühendislik, Bilim ve Teknoloji Dergisi, 23 (1), 2008, s. 67-78.

${ }^{19}$ Ali K1lc1, Anadolu Türk Mimarisinde Erken Devir (14-15. yy.) Baldaken Tarzı Türbeler, Vakıflar Genel Müdürlüğü Yayınları, Ankara; Ali Kılcı, "Balkanlardaki Osmanlı Baldaken Türbeleri Hakkında Bir Değerlendirme, Vakıflar Dergisi, Sayı: 32, s. 91-142.
} 
Baldaken tarzındaki Sadık Paşa Türbesi sekizgen planlı olup, sekiz ayağa oturmaktadır. Ayaklar üç dilimli yonca yaprağı biçimindedir. Türbe ayakları yuvarlak kemerlerle birbirine bağlı ve üstüne kubbe oturtulacak biçimde inşa edilmiştir. Ayaklar taş kaidelerin üzerlerine oturtulmuşlardır ve taş sütun başları vardır. Yapılan müdahaleler sırasında güçlendirme amaçlı ayaklar sütun başlarından birbirlerine demir gergilerle bağlanmıştır. Tamamen kesme taştan yapılan türbenin içinde iki kabir bulunmaktadır. Kabirlerden Hicrî 1210 (Milâdî 1795-96) tarihli olanı Sadık Paşa'ya, diğer Hicrî 1222 (Milâdî 1807-1808) tarihli mezar taşı ise Şeyh Abdu'l Osman'a aittir. Her iki kabrin baş ve ayak taşları bulunmaktadır. ${ }^{20}$

Günümüzde türbenin üzerinde kubbe bulunmamaktadır. Uzun süreli doğal etkilerden ve bakımsızlıktan dolayı türbe yapısının ayakları, kemerleri ve duvarları oldukça kötü durumdadır. Tuzlanma, çiçeklenme, renk değişimi, dökülme ve kararmalar gözle görülebilen hasarlardır. Türbenin daha fazla zarara uğramaması için acil bakıma ihtiyacı bulunmaktadır.

Sadık Paşa'ya ait mezarın şahidesinin üst kısmı asker fesi şeklindedir. Mezarın başlık kısmından da defnedilen kişinin bir 'Paşa' olduğu anlaşılmaktadır. Şeyh Abdü'l Osman'a ait olan mezarın baş taşının kavuklu olması; merhumun ilim ve irfanla uğraşan bir tarikat şeyhi olduğuna işaret etmektedir. Mezarın ayak taşının iç yüzünün üst kısmında 12 dilimli Bektaşî sikkesinin olması, mezarın bir Bektaşî şeyhine ait olduğuna işaret etmektedir. Bilindiği üzere 12 dilim, 12 imamı sembolize etmektedir (Şekil 12).
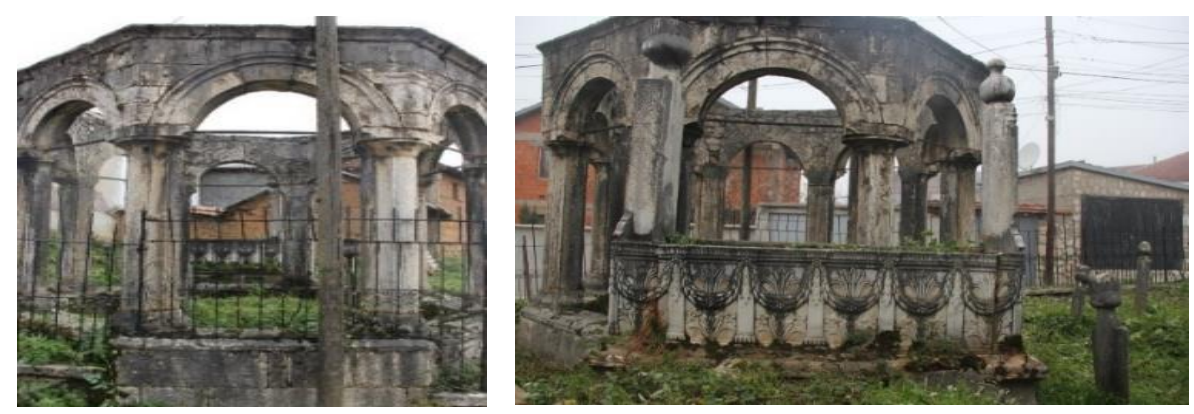

Şekil 12. Sadık Paşa Türbesi mevcut durumu

\footnotetext{
${ }^{20}$ Ali Kılc1, a.g.e.
} 


\section{DEBRE FATIHH SULTAN MEHMED (HÜNKÂR) CAMİSI}

Sadık Paşa Türbesi, Balkanlar'da Baldaken tarzında sekizgen plan şemasına sahip iki türbeden biridir (Şekil 13). Diğeri Arnavutluk'un başkenti Tiran'da bulunan Kaplan Paşa Türbesidir. ${ }^{21}$

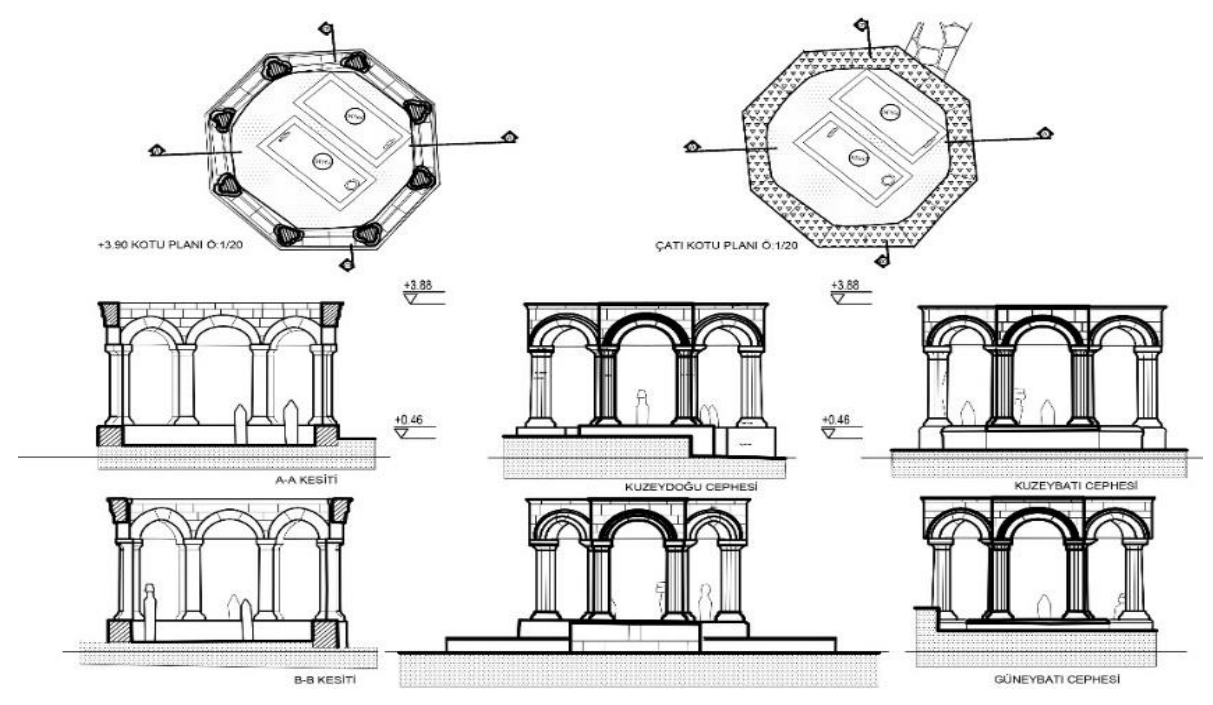

Şekil 13. Sadık Paşa Türbesi Plan-Kesit ve görünüşleri

\subsubsection{Cephe Karakteri}

Cephelerin tamamı günümüzde çimento esaslı sıva üzeri boyalıdır. Yapının orijinal pencere kanatları pvc ile değiştirilmiştir. Son cemaat bölümünün de harim kısmı ile aynı çatı altına alınması ile beraber özgün cephe karakteri büyük ölçüde değiştirilmiştir.

Yapının ana giriş kapısı, kuzeybatı yönündeki cephenin tam ortasında bulunmaktadır. Kapının üzerinde yuvarlak kemerli kare formlu bir pencere yer almaktadır. Kapının orta aksında cephede simetri söz konusudur. Giriş kapısının sağında ve solunda yine yuvarlak kemerli ikişer dikdörtgen pencere daha bulunmaktadır. Pencerelerin denizlikleri dışa çıkıntılı ve mozaiktir. Cephede pencere kenarları zemine kadar sarı boyalıdır. Yine kapının sağında ve solunda tuğladan örülerek yapılmış duvar içine gömülü üçerden, toplam altı adet ayak yer almaktadır. Cephe ahşap Marsilya kiremitli kırma çatı ile sonlanmaktadır. Cephedeki kapı ve pencere doğramalarının tamamı pvc

${ }^{21}$ Kilc1, a.g.m. 
esaslıdır. Ayaklar kireç badana, cephenin diğer kısımları ise çimento esaslı sıva üzeri boyadır. Cephenin güneybatısında ise minare bulunmaktadır. Minareye çıkış merdiveninin taş kaidedeki demir kapısı bu cephede görülebilmektedir. Kuzeydoğusunda ise şadırvan yer almaktadır. Cephede yer yer çatlaklar, dökülmeler ve kirlenmeler görülmektedir.
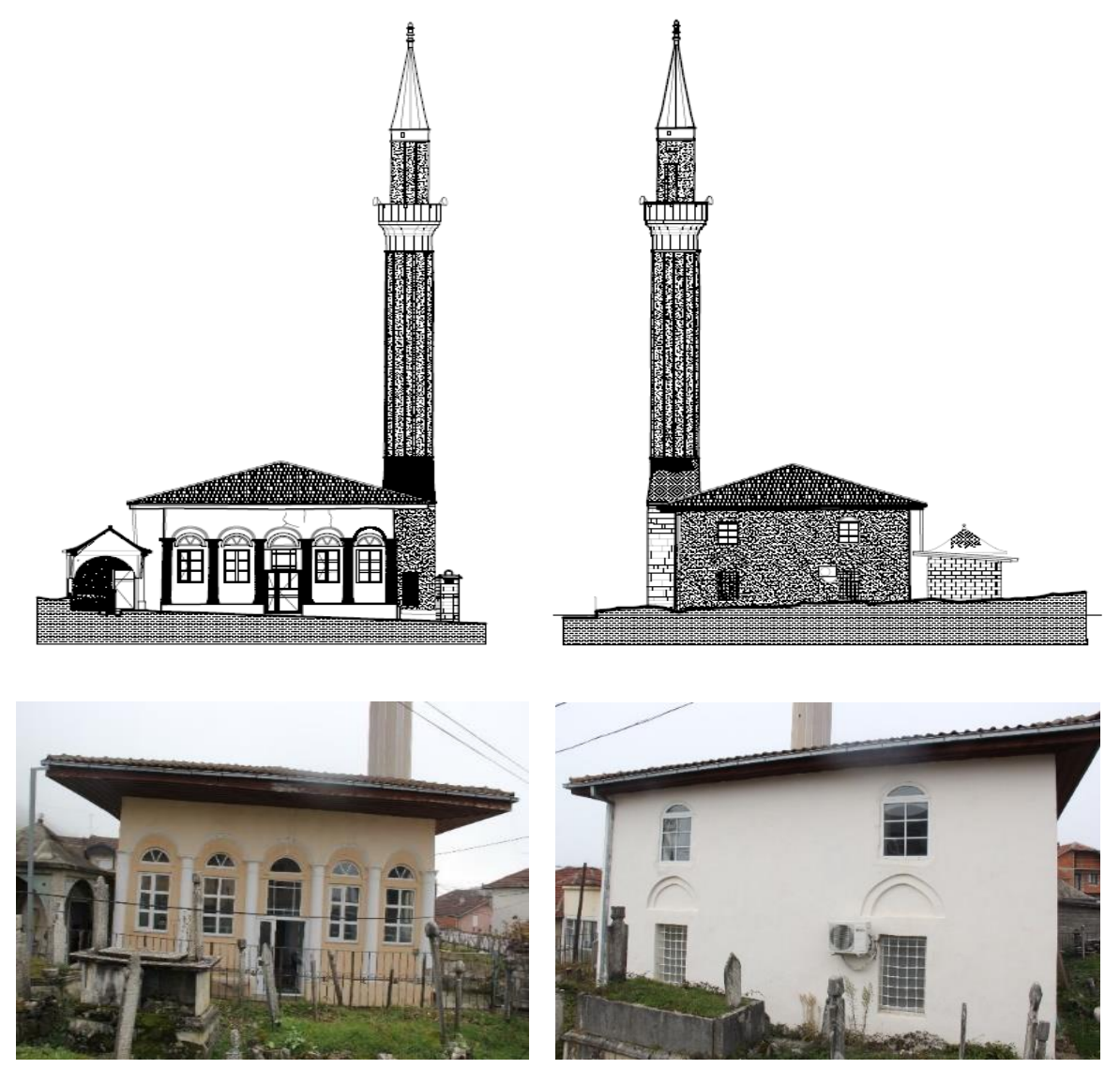

Şekil 14. Cami kuzeybatı ve güneydoğu cephe karakteristiği

Ana giriş cephesinin tam karşısında, kıble yönü olan güneydoğu cephesi bulunur. Mihrap nişi düz bırakılarak, cephede fark ettirilmemiştir. Mihrabın iki yanındaki pencereler, dikdörtgen ile burada yer alırlar. $\mathrm{Bu}$ pencerelerin üzerinde kemerli üst kot pencereleri yer almaktadır. Cephe Marsilya kiremit kaplı kırma çatı ile bitmektedir. Alt kottakiler sivri kemerli 


\section{DEBRE FATIHH SULTAN MEHMED (HÜNKÂR) CAMİSI}

ve dikdörtgen formludur. Üst kottakiler ise yuvarlak kemerlidir. Cephe ahşap Marsilya kiremit kaplı kırma çatı ile bitmektedir. Alt kot pencerelerinde lokmalı demir parmaklıklar bulunmaktadır. Cephedeki dört adet pencerenin tamamı pvc esaslıdır. Cephe kireç badana ile kaplanmıştır. Bu cephenin gerisinde kuzeydoğusunda, briket duvarlı tuvalet bölümü görülmektedir. Güneybatısında ise minare yer almaktadır.
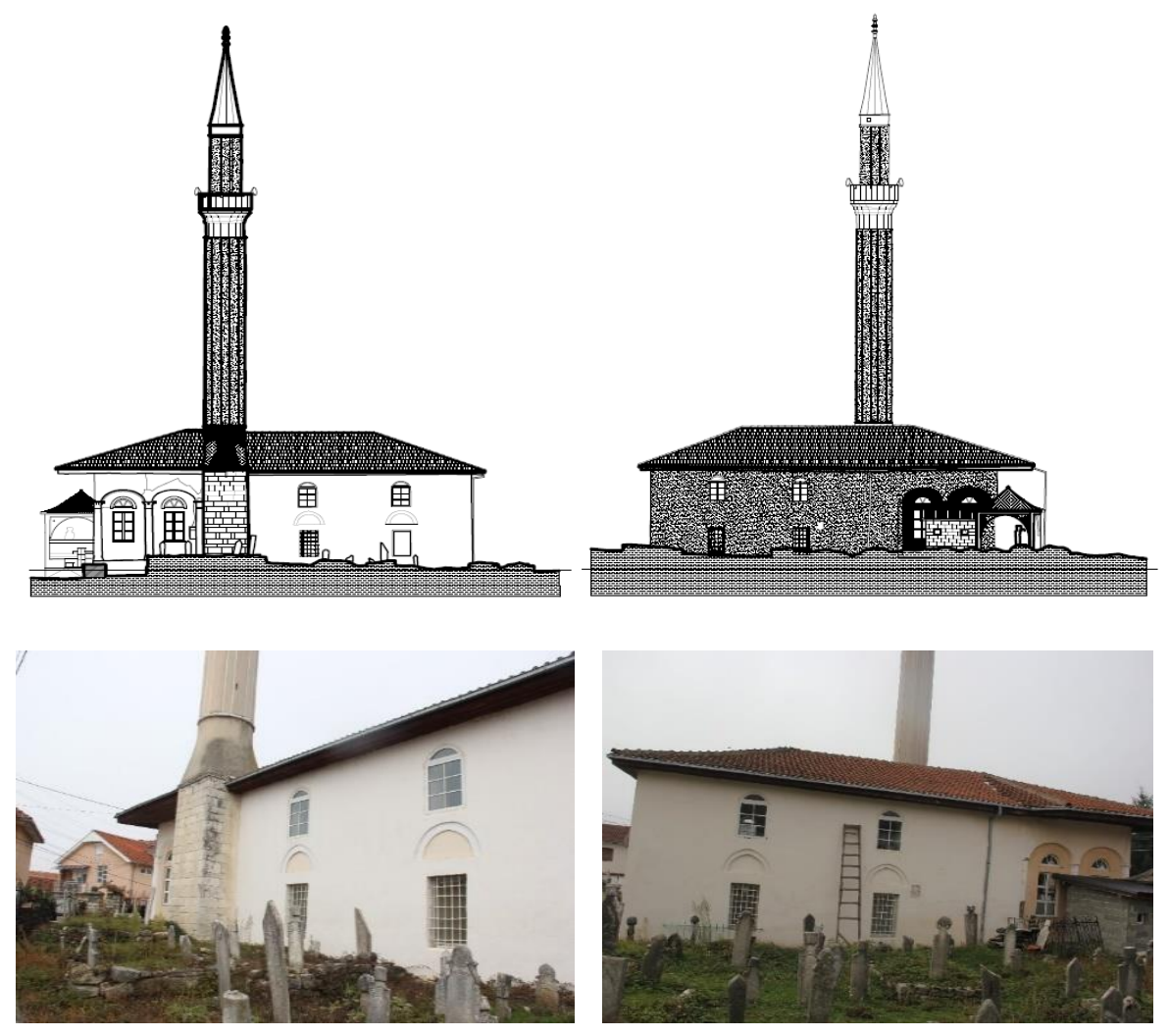

Şekil 15. Cami kuzeydoğu ve güneybatı cephe karakteristiği

Güneybatı cephesinde düzgün kesme taş kaideli minare yer almaktadır. Minarenin güneydoğusunda harim kısmı bulunur. Harim bölümünde alt kotta dikdörtgen formlu, lokma demirli iki adet pencere vardır. Pencerelerin üzerinde yuvarlak kemerli nişler yer alır. Onların üzerinde üst kotta da kemerli iki adet pencere bulunur. Bu bölümde duvarlar kireç badanadır. Minarenin kuzeybatısında son cemaat bölümünün yuvarlak 
kemerli iki adet dikdörtgen penceresi bulunur. Bu bölümde üç adet duvara gömülü ayak da yer almaktadır. Ayaklar kireç badana, duvarlar sıva üzeri boya, pencere kenarları ise sarı boyalıdır. Cephe ahşap Marsilya kiremiti kaplı kırma çatı ile sonlandırılmıştır.

Kuzeydoğu cephesinde de harim ve son cemaat bölümleri ayrı olarak algilanabilmektedir. Günümüzde tuvaletler son cemaat bölümünün önüne geldikleri için cephede son cemaat bölümünün briket duvarlı tuvalet mekânı görülmektedir. Arkasında ise güneybatı cephedeki özelliklerinin ve elemanlarının aynısı ile son cemaat mahalli bulunmaktadır. Tuvaletlerin yanında ise şadırvan vardır. Şadırvan bölümü ise mozaik kaplama ve kireç badana ile kaplanmıştır. Şadırvanda yer yer kirlenmeler mevcuttur. Cephenin harim bölümünde dikdörtgen formlu, lokma demirli iki adet pencere vardır. Pencerelerin üzerinde sivri kemerli nişler, onlarında üzerinde yuvarlak kemerli iki adet pencere bulunmaktadır. $\mathrm{Bu}$ bölümde duvarlar kireç badanadır. Bu cephede ahşap Marsilya kiremit kaplı kırma çatı ile tamamlanmaktadir.

\section{Sonuç}

Balkan coğrafyası Osmanlı medeniyetinin en önemli kültürel miras varlığına sahip bölgelerdendir. Bu yapıların özgün karakteri ile korunması ve gelecek nesillere aktarılması, kültürel sürdürülebilirliğin sağlanması için oldukça önemlidir. Bu yapıların bir kısmı özgün karakterini korurken, büyük bir kısmı ise çeşitli bozulmalar ve eklentilerle özgün karakterini kaybetme riski ile karşı karşıyadır. Bu nedenle Balkanlardaki kültürel mirasın önemli bir parçası olan Osmanlı mimari mirasının özgün karakterlerine uygun koruma-restorasyon müdahaleleri önem kazanmaktadır.

$\mathrm{Bu}$ araştırma kapsamında Debre kasabasında Hünkâr (Hunkar) Camisi olarak da bilinen Fatih Sultan Mehmed Camisi incelenmektedir. Bina, 1467 yılında Fatih Sultan Mehmed Han tarafından inşa ettirilmiştir. Hünkâr Camisi Makedonya'da ayakta kalan tek fetih camisidir. Cami aynı zamanda Debre'de Osmanlı dönemi eserleri içerisinde günümüze ulaşmış tek cami yapısıdır. Cami genişçe bir hazire içerisinde bulunmaktadır. Yapı plan tipolojisi yönüyle erken Osmanlı dönemi özelliklerini taşımaktadır.

Rölöve çalışmaları esnasında yapıda bazı bozulmaların meydana geldiği tespit edilmiştir. Harim kısmı planimetrik özelliğini korumuş olsa da, 


\section{DEBRE FATIHH SULTAN MEHMED (HÜNKÂR) CAMİSI}

yapının orijinal yapı elemanlarının bozulduğu gözlemlenmiştir. Cami ana binasının duvarlarında kılcal çatlaklara rastlansa da büyük ölçüde sağlamlığını korumuştur. Ancak duvarları daha sonraki dönemlerde çimento esaslı sıva ve yağlı boya ile boyanmıştır. Çimento katkılı yapı malzemelerin kesme taştan yapılmış mevcut yapıya zarar verdiği, dolayısıyla bu bölgelerin temizlenerek yapıdan uzaklaştırılması oldukça önemlidir. Harimin iç mekânındaki yağlı boyalarında dikkatlice kaldırılması, özellikle badanalı bölgelerde kalem işleri çıkma olasılığına karşı titiz bir çalışma sergilenmelidir. Yapının kapı ve pencere doğramaları da orijinal elemanlarını kaybetmiş olmasına rağmen kullanılan pvc malzeme tarihi yapı ile hiç uyuşmamaktadır. Bu doğramaların tekrar ahşap malzemeye dönüştürülmesi gerekmektedir. Son cemaat bölümündeki planimetrik değişiklik kesin olarak bilinmediği için mevcut çatı altında korunması uygun olacaktır. Fakat kapalı olan bu bölgenin tekrar açılması özgün karakterin ortaya çıkarılmasına katkı sağlayacaktır.

Benzer durum caminin minare elemanında da gözlenmektedir. Bina ve saha tespit çalışmaları esnasında açılan muayene kuyuları ile minare temelinin sağlamlığını koruduğu görülmüştür. Ancak minarenin kesme taş yap1 malzemesinde erime ve kopmaların olduğu, bu bölümlerin bir bölümünün çimento esaslı mozaik malzeme ile kaplandığı tespit edilmiştir. Kaplanan malzemeden kaynaklı alüminat tuz oluşumu, taşın yapısının daha fazla bozucu etkiler oluşturduğundan dolayı yapıyı güçlendirme olanakları da oldukça zayıflatmıştır. Diğer taraftan minare yapısının da dış cephesi, çimento esaslı mozaik ile kaplanmıştır. Bu kaplama minare yapısının yanal etkiler altında sürekliliğini artıracak bir donatı elemanının içermemektedir. Yanal etkiler altında bu kısımların çekme dayanımının düşük olmasından dolayı yapının orijinal kesme taş duvar örgüsünden önce çekme dayanımının aşılmasına neden olacağı düşünülmelidir. Böyle bir durumun, yapıda ani bir gerilme boşalması meydana getirmesi de yüksek düzeyde olasıdır. Bu durum normal şartlar altında yapıda meydana gelmeyecek seviyede darbe etkisi yaratarak çekme gerilimlerini artırması ile ciddi hasarlar meydana getirmesi kaçınılmaz görünmektedir. Bununla birlikte mozaik kaplamanın minare üzerine getirdiği ilave yük getirdiği de gözden kaçırılmamalıdır. Bu nedenle yapının restorasyonu veya onarımı aşamasında bu tabakanın yapıdan uzaklaştırılması gerektiği düşünülmektedir. Bu çerçevede, minarenin pabuç kısmı hariç tüm kısmının sökülerek orijinal malzeme ile yeniden inşa edilmesinin, yapının özgün görüntüsüne dönüşmesi ve minarenin sağlamlığ 1 için gerekli görülmektedir. 


\section{TÜLAY KARADAYI YENICE - BARIŞ GÖREN}

Yapının orijinal cephe görünümlerinin de tekrar açığa çıkarılması gerekmektedir. Bu nedenle dış cephede de boya ve badanaların temizlenmesi gerekmektedir. $\mathrm{Bu}$ temizleme işleminden sonra eksik, zarar görmüş malzemeler orijinaline uygun tamamlanmalıdır. Ahşap doğramalar cephede de görünür hale gelerek, lokmalı demir parmaklıklara gerekli bakımlar yapılmalıdır. Üst kot pencerelerine dönem örneklerine ve yapının eski fotoğraflarına bakılarak tamamlanmalıdır.

Araştırma sonucunda elde edilen bulguların, yapının restorasyon aşamasında doğru müdahaleler yapılmasına yardımcı olacağ 1 düşünülmektedir. Yapılan müdahalenin doğru yapılması yapının sürekliliğini de sağlayacaktır. Bu sayede Osmanlı İmparatorluğu'nun Balkanlardaki önemli eserlerinden biri olan Debre Fatih Sultan Mehmed (Hünkâr) Camisi özgün karakteri ile dünya mimarlık tarihindeki yerini alması ve gelecek nesillere doğru aktarımı sağlanacaktır.

YAZAR NOTU: Bu çalışma, başlıca yazar Tülay Karadayı Yenice danışmanlığında, ikinci yazar Mimar Barış GÖREN müellifliğinde, T.C. Kültür ve Turizm Bakanlığı, Türk İşbirliği ve Koordinasyon Ajans1 Başkanlığı (TİKA) tarafından desteklenen Debre Hünkâr Camii RölöveRestitüsyon ve Restorasyon Projelerinin Hazırlanması işi kapsamında elde edilen bulgulara dayalı olarak hazırlanmıştır.

\section{KAYNAKÇA}

\section{Arşiv Kaynakları}

BOA, DH.MKT, 1467/30.

BOA, DH.MKT, 1594/94.

BOA, DH.MKT, 1428/113.

\section{Araştırma Eserler}

AYVERDİ, Ekrem Hakkı, Avrupa'da Osmanlı Mimari Eserleri - Yugoslavya, C. 2, İstanbul 2000. 


\section{DEBRE FATIHH SULTAN MEHMED (HÜNKÂR) CAMİSI}

DÜLGERLER Osman Nuri, KARADAYI, Tülay, "Türklerde Anıt Mimarisinin Bir Örneği; Konya Atatürk Anıtı", Selçuk Üniversitesi Mühendislik, Bilim ve Teknoloji Dergisi, 23 (1), 2008, s. 67-78.

GÜLER, Ali, Atatürk'ün Soyu, Klzıloğuzlar ve Konyarlar, Berikan Yayınları, İstanbul 2014.

GÜRAY GÜLYÜZ, Bahriye, "Osmanlı Geleneğinde Sakal-1 Şerifin Yeri ve Bulgaristan'da Sakal-1 Şerif Muhafazalı Camiler", Balkan Araştırma Enstitüsü Dergisi, Cilt 8, Sayı 1, 2019, s. 85-111.

İBRAHIMGİL, Mehmet Zeki, "Balkanlar'daki Fatih Sultan Mehmed Camileri”, Balkanlarda İslam Medeniyeti II, Milletlerarası Sempozyumu Tebliğleri, Tiran Arnavutluk 4-7 Aralık 2003, s. 513-530.

, "Evliya Çelebi Seyahatnamesinde Ohri Sancağı", Sanat Tarihi Dergisi, Cilt: 22, Say1: 1, Nisan 2013, s. 11.

Kâtip ÇELEBİ, Cihannümâ - İklîm-i Rum, C. I, İstanbul 1971.

KILCI, Ali, "Balkanlardaki Osmanlı Baldaken Türbeleri Hakkında Bir Değerlendirme", Vakıflar Dergisi, Say1: 32, s. 91-142.

, Anadolu Türk Mimarisinde Erken Devir (14-15 yy.) Baldaken Tarzı Türbeler, Vakıflar Genel Müdürlüğü Yayınları, Ankara.

NURESKİ, Djuneis, "Osmanlı Kaynaklarına Göre Kültür Merkezi Konumundaki Makedonya Şehirleri ve Özellikleri”, Balkan Araştırma Enstitüsü Dergisi, Cilt 3, Say1 1, 2014, s. 63-102.

SHCHEGLOV, Dmitry A., Eratosthenes' Contribution to Ptolemy's Map of the World, The International Journal for the History of Cartography, 69:2, 2017, s. 159-175.

SHUKAROVA, Aneta, PANOV, Mitko B., GEORGIEVV, Dragi, BİTOVSKİ, Krste, KATARDZIEV, Ivan, STOJCHEV, Vanche, VELJANOVSKİ, Novica ve CHEPREGANOV, Todor, History of the Macedonian People, Ed. Todor Chepreganov, Institute of National History Skopje 2008. 


\section{TÜLAY KARADAYI YENICE - BARIŞ GÖREN}

STOJANOVSKI, Aleksander, Makedonija vo Turskoto Srednovekovie, Kultura, Skopje 1989.

UZUNÇARŞILI, İsmail Hakkı, Osmanlı Tarihi, C. 1, Türk Tarih Kurumu Basımevi, Ankara 2011.

VON HAHN J. George, Reise durch die Gebiete des Drin und Wardar im auftrage der Kaiserl. Akademie der Wissenschaften, unternommen im Jahre 1863, Wien 1865, s. 360-364. (urn:nbn:de:bvb:355-ubr05324-0003-9).

YILMAZ Edip, ELMAS Erdal, “Ohri'deki (Makedonya) Osmanlı Dönemi Camileri”, Anasay, Say1 4, 2018, s.47-82.

\section{İnternet Kaynakları}

http://www.stat.gov.mk/PrikaziPoslednaPublikacija.aspx?id=11, (21.03.2019).

KIEL, Machiel, "Debre", İslam Ansiklopedisi, https://islamansiklopedisi.org.tr/debre, (18.02.2019). 